\title{
Effects of phonological awareness and phonological processing on language skills in 4- to 6-year old children with and without language delay*
}

\author{
Shinyoung Kim $\cdot$ Jinkyeong Son $\cdot$ Dongsun Yim** \\ Department of Communication Disorders, Ewha Womans University, Seoul, Korea
}

\begin{abstract}
Phonological awareness is a metalinguistic awareness ability of phonology and is known to predict language skills, such as reading and vocabulary skills. The purpose of this study was to investigate the relationship between phonological awareness, phonological processing, and language skills in 4- to 6-years-old typically developing (TD) children and children with language delay $(\mathrm{LD})$. A total of 32 children $(\mathrm{TD}=18, \mathrm{LD}=15)$ participated in this study. They performed a phonological awareness task consisting of counting, deletion, and discrimination at syllable level. Nonword Repetition, Digit Backward, Receptive \& Expressive Vocabulary Test, and Grammaticality Judgment Task were performed to analyze the correlation between phonological awareness, phonological processing, and language ability. A multiple stepwise regression analysis was performed to examine the phonological awareness subtasks that predict language ability. In the TD group, the syllable categorization task significantly predicted the receptive vocabulary and the performance of the Grammaticality Judgment Task. The LD group showed that the syllable counting task significantly predicted the receptive vocabulary, the expressive vocabulary, and the performance of the Grammaticality Judgment Task. The results showed that the phonological awareness performance was significantly different between the two groups. Further, correlation analysis and regression analysis showed different results for each group. The result of the phonological awareness performance predicted the language ability of each group significantly, suggesting the importance of the meta-linguistic awareness ability of phonology.
\end{abstract}

Keywords: phonological awareness, phonological processing, metalinguistic awareness, vocabulary skills, grammaticality judgment

\section{1. 서론}

상위언어인식(metalinguistic awareness)이란 언어 자체를 사 고의 대상으로 취급하면서 언어의 구조적 특성을 이해하고 조

\footnotetext{
* This work was supported by the Ministry of Education of the Republic of Korea and the National Research Foundation of Korea (NRF-2018S1A3A 2075274)

** sunyim@ewha.ac.kr, Corresponding author

Received 31 October 2019; Revised 16 January 2020; Accepted 16 January 2020

(c) Copyright 2020 Korean Society of Speech Sciences. This is an Open-Access article distributed under the terms of the Creative Commons Attribution NonCommercial License (http://creativecommons.org/licenses/by-nc/4.0) which permits unrestricted non-commercial use, distribution, and reproduction in any medium, provided the original work is properly cited.
} 
작할 수 있는 능력을 말한다. 메타언어(metalanguage)와는 구분 할 필요가 있는데, 메타언어가 음소, 낱말, 구문 등의 용어에 대 한 지식과 같이 언어 그 자체를 설명하는 데에 사용된다면, 상 위언어인식은 이러한 용어가 무엇인지 아는 것을 의미하는 것 이 아닌, 그러한 용어가 가진 예화(instantiation)에 대한 지식을 의미한다. 그러므로 상위언어인식 능력이 발달한다면 ‘음소'라 는 용어의 뜻이 무엇인지 알지 못하더라도 음소를 인지하고 조 작하는 것이 가능하다(Tunmer \& Herriman, 1984). 이러한 상위 언어인식 능력은 크게 음운인식(phonological awareness), 단어 인식(word awareness), 구문/통사인식(syntactic awareness), 화용 인식(pragmatic awareness)의 네 가지 영역으로 구분할 수 있으 며, 이 중에서 특히 음운인식, 단어인식, 그리고 구문/통사인식 능력은 아동들의 읽기 및 단어학습 능력에 영향을 미치는 것으 로 많은 연구들에서 증명되어 왔다(Anthony et al., 2002; Owen \& Leonard, 2001; Stark \& Heinz, 1996).

음운론적 측면에서의 상위언어인식 능력이라고 할 수 있는 음운인식은 말소리의 음운론적 요소와 그 체계를 인식하고 그 것을 조작하는 능력을 말한다(Nathan et al., 2004). 말소리의 유 사성과 상이성을 변별하는 능력이라고도 정의할 수 있으며 (Dixon, 2010), 따라서 아동이 음운인식 능력을 가졌다는 것은 말소리의 구조를 인식하고 분석할 수 있는 능력을 지닌다는 것 을 의미한다(Schuele \& Boudreau, 2008). 음운인식 능력이 발달 하면 여러 단계의 다양한 음운 지식을 다룰 수 있게 된다. 음운 인식 능력은 일반적인 말소리의 구조를 인지하는 기본적인 단 계로부터 시작하는데, 영어권의 연구를 살펴보면 단어를 음절 단위로 인지하는 것으로부터 같은 소리의 각운(rhyme)들에 대 한 인식, 보다 심층적으로는 초두자음(onset)과 각운(rime)을 인 지하고 추출해내는 능력과 같이 음소를 조작하는 기술로 발전 한다(Schuele \& Boudreau, 2008). 음운인식의 발달단계에 대한 지식을 기초로 음운인식 과제를 난이도에 따라 분류할 수 있는 데, 음절 단위로 말소리를 조작하는 수준의 음절 수준의 음운인 식 과제보다 음소를 분리하는 것과 같은 음소 수준의 음운인식 과제가 보다 난이도가 높은 과제이며, 많은 연구들에서 $5 \sim 6$ 세 가 되어야 음소 수준의 말소리를 탐지할 수 있는 것으로 밝혀 왔다(Gillon \& McNeill, 2009; Liberman et al., 1974).

음운인식 능력은 언어권에 상관없이 생활연령이 높아짐에 따라 발달하는 것으로 다양한 선행연구들에서 밝혀왔는데(Felton \& Pepper, 1995; Ziegler \& Goswami, 2005), 구체적으로 Liberman 과 그 동료들은 미국의 3 6세 아동을 대상으로 단어를 음절 및 음소 수준으로 분절하는 과제를 실시하고 연령별 음운인식 능 력을 비교 검토하였다(Liberman et al., 1974). 그 결과 평균월령 이 59개월인 4 5세 아동들의 경우 음소분절은 불가능하였고 음절분석은 전체 아동의 $46 \%$ 만이 가능하였다. 평균월령이 70 개 월인 $5 \sim 6$ 세 아동들의 경우 음소분절은 $17 \%$, 음절분절은 $48 \%$ 의 수행력을 보였으며, 학령기에 접어든 1 학년 아동들은 음소 분절은 $70 \%$, 음절분절은 $90 \%$ 의 수행력을 보였다. 한국 아동들 을 대상으로 한 다수의 선행연구에서도 아동들의 연령이 높아 질수록 음운인식 능력이 발달함을 확인하였으며(Ahn et al.,
2011; Hong et al., 2002; Kim \& Kim, 2006; Kim \& Pae, 2007; Kim et al., 2018; Park, 2000; Shin et al., 2009), 4 6세의 아동들을 대 상으로 한 연구에서는 음절 수준의 음운인식 능력은 4세에 습 득되기 시작하여 5 세에 거의 습득하고, 음소 수준의 음운인식 능력은 4 5세 경에는 거의 발달하지 않다가 6세가 되어서야 본격적으로 발달하는 것을 확인한 바 있다(Shin et al., 2009). $4 \sim 7$ 세의 아동들 1,043 명을 대상으로 한 국내 연구에서도 마찬 가지로 음절인식 능력은 연령이 증가함에 따라 점차적으로 발 달하는 데 반해, 음소인식 능력은 66개월 이하 집단은 수행력에 차이가 없다가 67개월 이후 집단부터 수행력이 빠르게 향상됨 을 근거로, 5 세 후반이 되어서야 음소 수준에서 말소리를 인식 하는 능력이 발달한다고 하였다(Ahn et al., 2011). 학령전기 아 동과 학령기 아동의 음운인식 수행력을 비교한 연구에서도 대 부분의 음절수준 음운인식 과제는 학령전기와 학령기 집단 간 유의한 차이가 없었으나 모든 음소수준 과제에서 학령전기와 학령기 집단 간 유의한 차이가 있는 것으로 나타난 결과는, 음 소수준의 음운인식 능력은 학령기까지 지속적으로 발달함을 확인한 연구라고 할 수 있다(Kim \& Pae, 2007).

음운인식 과제의 유형으로는 음절 및 음소 수준에서 수세기, 합성, 탈락, 변별, 대치 등이 있다. 과제 유형별 발달 순서는 연 령, 언어 단위, 또는 언어권의 특징에 따른 연구마다 일관되지 않은 결과를 보인다. $5 \sim 7$ 세의 아동들을 대상으로 한 국내 연구 에서는 과제의 유형별 수행력의 순서가 연령집단별로 서로 다 르게 나타났다(Kim et al., 2010). 4 7세 아동들을 대상으로 한 대규모 연구에서는 음절 수준에서 수세기, 탈락, 합성, 변별, 대 치 과제 순으로 점수가 높았으나, 음소 수준에서는 수세기, 변 별, 탈락, 합성, 대치 순으로 점수가 높았다(Ahn at al., 2011). 4 6세 아동 72명을 대상으로 한 연구에서도 음소 및 음절 수준에 서 각각 세 가지 종류의 음운인식 과제(탈락, 합성, 변별) 수행력 을 비교한 결과, 과제의 종류와 연령의 상호작용 효과가 유의한 것으로 나타나 연령집단별로 음운인식 과제 수행률이 서로 다 른 것으로 보고되었다(Hong et al., 2002). 한편 Yopp(1988)은 음 운인식 과제 유형별로 요인분석을 실시하였으며, 그 결과 음소 수세기, 음소합성, 음소분절, 음소분리가 하나의 요인으로 묶이 고, 음소탈락이 또 다른 요인으로 분류되었다. 이에 대해 음소 탈락이 다른 과제들에 비해 복잡한 처리과정을 요하는 과제인 것으로 설명하였는데, 이는 앞선 국내 연구 결과와 일치하지 않 는 결과이다.

음운인식 능력은 많은 연구들에서 특히 초기 읽기능력의 중 요한 예측 변인으로서 주목해 왔는데(Ehri et al., 2001; Lonigan et al., 2000; Stanovich, 1992; Wagner \& Torgesen, 1987), 음절, 각 운, 음절체, 음소 등에 대한 탐지 및 조작 능력이 높은 아동들은 낱말 해독이 보다 수월해짐으로써 읽기에 이점을 얻게 된다 (Bus \& van IJzendoorn, 1999). 난독증에서 보여지는 단어재인의 어려움, 음소와 자소 간 연결의 어려움 등 주요 특징들의 기저 에 음운인식 결핍이 있음을 주장하는 선행연구들 또한 음운인 식 능력과 읽기능력 간의 관련성을 뒷받침한다(Bruck, 1992; Snowling, 1998; Swan \& Goswami, 1997). Wagner \& Torgesen 
(1987)은 읽기를 예측하는 음운처리 능력을 검토하면서, 음운처 리 능력을 음운인식, 어휘 접근에 있어서의 음운 재부호화 (phonological recoding), 작업기억에 있어서의 음성 재부호화 (phonetic recoding) 세 가지로 나누어 분석하였다. 이들은 종단연 구 및 중재연구에 대한 체계적 분석을 통하여 세 가지 음운처리 능력 중 특히 음운인식 능력이 읽기의 예측 요인임을 밝혔는데, 이러한 연구 결과는 음운인식 능력이 읽기에 미치는 독립적인 영향을 밝혔다는 데에 의의가 있다.

한편 음운인식 능력과 어휘력 간의 관계에 대해서는 상반된 연구 결과들이 공존한다. Gathercole과 그 동료들은 4 5세 아동 들을 대상으로 음운인식, 음운기억, 그리고 어휘 및 읽기 능력 간의 관계에 대해 검토하였다(Gathercole et al., 1991). 이들은 요 인분석 결과를 토대로 각운(rhyme)인식 과제로 측정한 음운인 식 능력과 비단어따라말하기, 숫자 회상하기 과제로 측정한 음 운기억은 동일한 음운처리 능력을 공유한다고 주장하였으며, 이 두 가지 음운 관련 능력은 읽기 및 어휘 발달에 있어서 서로 다른 연관성을 갖고 있음을 밝혔다. 이 연구 결과에 따르면 음 운기억 능력은 읽기 및 어휘 발달을 유의하게 예측하는 것으로 나타났으나, 음운인식 능력은 읽기의 경우에는 연령에 따라 그 상관관계가 달랐으며 어휘 발달의 경우 음운인식은 어떤 연령 집단에서도 유의한 예측변수로 나타나지 않았다. 한편 Metsala \& Walley(1998)는 마찬가지로 4 5세의 아동들을 대상으로 음 운인식과 음운기억, 그리고 어휘능력 간의 관계를 검토하였는 데, 이 연구에서는 비단어따라말하기 및 숫자/낱말 회상하기로 측정한 음운 단기기억 능력이 아동들의 어휘능력을 설명하지 못한 반면, 음운인식 능력이 아동들의 어휘능력에 대한 유의한 설명력을 갖는 것으로 나타났다. 이러한 연구 결과를 근거로, Metsala는 음운인식 능력이 어휘능력 발달과 밀접하게 연관되 어 있음을 주장하였다.

다양한 언어장애 아동들의 음운인식 능력에 결함이 있음을 밝힌 연구들도 음운인식 능력이 언어능력에 미치는 중요한 영 향을 강조한다(Catts, 1993; Owen \& Leonard, 2001; Stark \& Heinz, 1996). 특히 음운장애 아동들의 경우 낱자들이 갖고 있는 소리에 대한 지식은 비교적 온전함에도 불구하고 실제단어와 비단어의 읽기 및 쓰기에 어려움을 보임을 밝힌 선행연구는, 겉 으로 드러나는 말장애와 기초 문해능력 결함의 기저에 작은 단 위의 말소리를 조작하는 음운능력의 어려움이 있음을 주장하 였다(Bird et al., 1995). 국내의 선행연구에서도 4 5세의 단순언 어장애 아동(Kang \& Kim, 2007), 5 6세의 기능적 조음음운장 애 아동(Koa \& Kim, 2010), 초등학교 1학년의 발달성 난독 아동 (Yang \& Pae, 2018)을 대상으로 한 연구에서 실험집단은 모두 통제집단인 또래 일반아동에 비해 음운인식 과제의 수행력이 유의하게 낮았다. 아동의 언어능력을 언어성 지능지수와 언어 문제해결력을 기준으로 언어영재와 일반아동, 언어발달지체 아동의 세 집단으로 구분하여 음운인식 능력을 검토한 연구에 서도 마찬가지로 집단 간 음운인식 능력의 유의한 차이를 확인 하여 언어능력과 음운인식 능력 간 유의미한 관계가 있음을 밝 혔다(Shin et al., 2006).
또한 음운인식 중재연구는 음운인식 능력을 촉진하는 중재 의 효과를 검토함으로써 음운인식 능력이 언어능력에 미치는 영향을 확인할 수 있다. 중재 연구의 사례로, $5 \sim 7$ 세의 언어장 애 아동 61 명을 대상으로 음운인식 중재와 전통적 언어중재의 차이를 비교 검토한 Gillon(2000)의 연구를 들 수 있다. 연구 결 과 음운인식 중재 집단 아동들이 전통적 중재 집단 아동들에 비 해 음운인식 능력과 읽기가 유의하게 향상되었으며, 음운인식 능력이 또래 일반아동인 통제집단에 비해 유의하게 낮았던 중 재 전에 비해 음운인식 중재 이후 통제집단과 비슷한 수준으로 향상되었음을 확인하였다. 또한 음운인식 중재 집단의 조음 능 력도 중재 전에 비해 유의하게 높아져, 음운인식 중재가 언어장 애 아동들의 음운인식 능력뿐만 아니라 읽기능력과 말 산출 능 력에도 긍정적인 영향을 가져왔음을 보였다. 국내에서는 이와 같은 대규모 집단 중재연구는 찾아보기 어려우나, 단일대상연 구를 통해 음운인식 중재가 지적장애 아동의 음운인식과 단어 재인, 그리고 음운정확도의 유의한 향상을 가져왔음을 확인한 선행연구가 있으며(Kim et al., 2018), 음운인식 중재와 함께 음 운작업기억 훈련을 실시함으로써 읽기부진 아동의 읽기능력에 유의한 효과를 가져왔음을 확인한 선행연구로 음운인식 중재 의 효과를 확인할 수 있다(Kim et al., 2019).

구문 및 형태론 영역에서의 상위언어인식 능력인 구문/통사 인식 능력은 문장을 구성하고 있는 문법적 측면에 대한 인식을 의미하며(Tunmer \& Grieve, 1984), 제시된 문장의 순서의 정오 여부를 판단하고 수정하는 과제, 또는 문법적 오류를 판단하고 수정하는 과제를 통해 측정할 수 있다(Plaza \& Cohen, 2003; Tunmer et al., 1988). Smith-Lock(1995)은 단순언어장애 아동 집 단, 그리고 그 아동들과 언어연령 및 생활연령을 일치시킨 집단 간의 비교 연구를 통해 구문/통사인식 능력은 인지 및 생활연령 발달보다는 언어발달과 보다 관련이 있음을 주장하였다. Chaney (1992)는 음운인식, 단어인식, 구문/통사인식 능력 간 상관관계 를 검토하였는데, 세 가지 상위언어인식 능력 간 유의한 상관관 계를 확인하였으며, 또한 언어능력과의 상관관계도 분석한 결 과 전반적 상위언어인식 능력, 특히 음운인식 능력과 유의한 정 적인 상관관계가 나타났다.

음운인식에 어려움이 있는 아동들이 추후 읽기 및 어휘력에 어려움을 보임을 밝힌 종단연구들을 비롯하여(Lenchner et al., 1990; Snowling et al., 2000; Wagner et al., 1994), 음운인식 능력 과 읽기 및 어휘력 등 언어능력 간의 유의한 관계를 밝힌 선행 연구들을 바탕으로, 본 연구는 음운인식 능력이 언어발달지연 아동 및 일반아동의 언어능력을 서로 어떻게 다르게 예측하는 지 검토해보고자 한다. 본 연구에서 사용하는 음운인식 과제는 연구 대상 아동들의 연령을 고려하여, 6 세가 되어야 본격적으 로 발달하는 것으로 알려진 음소 수준의 과제를 제외한 음절 수 준의 과제만으로 구성하였다. 또한 문해능력이 아직 발달하지 않았거나 현재 발달하기 시작하고 있는 연구 대상 아동들의 연 령을 고려하여, 언어능력 평가 과제로서 읽기 과제는 배제하고 어휘력 검사와 문법성판단 과제를 선택하였다. 이를 통하여 음 운론적 측면에서의 상위언어인식 능력과 아동들의 어휘력, 그 
리고 구문/통사인식 능력 간의 관계를 구체적으로 파악해보고 자 한다. 또한 음운처리 능력을 문어 및 구어에서 음운 정보를 사용하는 능력으로 정의하고 음운인식, 음운작업기억, 음운재 부호화로 세분화하여 분석한 선행연구를 참고하여(Wagner \& Torgesen, 1987), 본 연구에서도 음운인식 능력과 기타 음운처리 과제 간의 상관관계 분석을 통하여 대상 아동들의 음운인식 능 력을 보다 상세히 검토하고자 하였다.

본 연구의 연구 질문은 다음과 같다.

1. 일반아동 집단과 언어발달지연 아동 집단 간 음운인식 하 위과제의 수행력에 차이가 있는가?

2. 일반아동 집단과 언어발달지연 아동 집단의 음운인식 하 위과제와 음운처리과제 및 언어능력 과제 간 상관관계가 다르게 나타나는가?

3. 일반아동 집단과 언어발달지연 아동 집단의 어휘 및 문법 성판단 능력을 유의하게 예측하는 음운인식 하위과제는 무엇인가?

\section{2. 연구 방법}

\section{1. 연구 대상}

본 연구는 경기 지역에 거주하는 만 $4 \sim 6$ 세 $(M=68.21$ 개월, $S D=7.052$ )의 언어발달지연 아동 15 명(남아 11 명, 여아 4 명)과 일반아동 18 명(남아 6 명, 여아 12명)을 대상으로 하였다. 모든 아동은 (1) 한국 카우프만 아동용 지능검사 (Korean Kaufman Assessment Battery for Children, K-ABC; Moon \& Byun, 2003) 결 과 비언어성 지능지수가 85(-1 SD) 이상이고, (2) 주양육자 또는 어린이집 및 유치원 교사에 의해 시각, 청각, 그리고 신경학적 결함 및 기타 정서장애가 없는 것으로 보고된 아동으로 선정하 였다.

대상 아동은 표준화된 언어검사인 취학전 아동의 수용언어 및 표현언어 발달 척도(Preschool Receptive Expressive Language Scale, PRES; Kim et al., 2011) 수행력에 따라 수용언어 또는 표 현언어 점수가 또래 규준 대비 $10 \%$ ile 미만인 경우 언어발달지 연 아동 집단으로, 수용언어와 표현언어 점수가 모두 또래 규준 대비 $10 \%$ ile보다 높을 경우 일반아동 집단으로 구분하였다. 본 연구에 참여한 대상 아동을 집단 간 연령, 비언어성 지능, 언어 능력에서 차이가 있는지 확인하기 위해 일원배치분산분석 (one-way ANOVA)을 실시하였다. 그 결과, 연령 및 비언어성 지 능지수에서 유의한 차이를 보이지 않았으나, 수용언어능력 $[F(1$, $31)=4.463, p=.043]$ 과 표현언어능력 $[F(1,31)=22.045, p<.001]$ 에서 유의한 차이가 나타났다. 연구 대상에 대한 정보는 표 1 에 제시 하였다.
표1. 연구대상 정보

Table 1. Participants' characteristics

\begin{tabular}{c|c|c|c|c}
\hline & $\mathrm{TD}(\mathrm{n}=18)$ & $\mathrm{LD}(\mathrm{n}=15)$ & \multirow{2}{*}{$F$-value } & \multirow{2}{*}{$p$-value } \\
\cline { 2 - 3 } & $\mathrm{M}(S D)$ & $\mathrm{M}(S D)$ & & \\
\hline Age & $67.72(7.442)$ & $68.8(6.763)$ & .186 & .669 \\
\hline K-ABC & $102.78(7.96)$ & $98.6(7.529)$ & 2.366 & .134 \\
\hline PRES-R & $51.11(9.029)$ & $44.20(9.741)$ & 4.463 & .043 \\
\hline PRES-E & $50.11(4.922)$ & $40.20(7.163)$ & 22.045 & $<.001$ \\
\hline
\end{tabular}

$\mathrm{TD}$, typically developing children; $\mathrm{LD}$, children with language delay; K-ABC, Korean Kaufman assessment battery for children (Moon \& Byun, 2003); PRES-R, preschool receptive expressive language scale-receptive (Kim et al., 2011); PRES-E, preschool receptive expressive language scale-expressive (Kim et al., 2011).

\section{2. 검사도구}

\subsection{1. 음운인식능력 평가}

본 연구에서는 아동의 음운인식능력을 평가하기 위해 Jung et al.(2015)의 음운인식 과제 중 세 가지의 하위과제를 사용하였 다. 각 과제는 10 개의 문항으로 구성되어 있으며, 문항별로 정 반응 했을 때 1점씩을 부여하여 각 하위과제의 총점은 10 점이 다. 모든 문항은 검사자가 구어로 제시하였으며, 연습문항을 통 해 아동이 과제를 충분히 이해했음을 확인한 후 본문항을 실시 하였다.

\subsubsection{1. 음절수세기}

음절수세기 과제는 아동에게 $1 \sim 3$ 음절의 낱말을 들려주고, 아동에게 각 낱말이 몇 개의 음절로 구성되어 있는지 확인하여 답하게 하였다. 연습문항에서 아동에게 목표낱말을 들려주면 서 글자 수대로 박수를 치게 하고, 각 낱말이 몇 개의 소리로 구 성되어 있는지 판단하여 답하도록 하였다. 본 연구에서 사용된 음절확인 하위과제는 1 음절 낱말 3 개, 2 음절 낱말 3 개, 3 음절 낱 말 2개, 4음절 낱말 2개로 구성되어 있다.

\subsubsection{2. 음절탈락}

음절탈락 과제는 다음절 낱말을 구성하고 있는 음절들 중 하 나를 제거하고 남은 음절들을 구어로 산출할 수 있는지를 평가 하였다. 검사자는 연습문항에서 아동에게 '첫 소리/끝 소리 빼기 놀이'를 하는 것으로 과제를 설명하였으며, 첫음절 탈락 5 문항, 끝음절 탈락 5 문항을 차례로 검사하였다. 음절탈락 하위과제는 2음절 낱말 5개, 3음절 낱말 5개로 구성되어 있다.

\subsubsection{3. 음절변별}

음절변별 과제는 아동에게 2음절 낱말 3개로 구성된 목록을 들려주고, 첫음절 또는 끝음절이 다른 낱말을 찾아서 답하도록 하였다. 검사자는 연습문항에서 아동에게 '앞 소리/끝 소리가 다 른 낱말 찾기 놀이'를 하는 것으로 과제를 설명하였으며, 첫음절 변별 5문항, 끝음절 변별 5문항을 차례로 검사하였다. 


\subsection{2. 음운처리능력 평가}

2.2.2.1. 비단어 따라말하기

본 연구에서 사용된 비단어 따라말하기 과제는 선행연구를 통해 그 임상적 유용성이 확인된 과제로서(Yim et al., 2017), 음 운단기기억을 측정한다. 검사자는 아동에게 비단어가 녹음된 음성파일을 들려주고, 아동이 비단어를 듣는 즉시 '앵무새처럼' 따라 말하도록 지시하였다. 본 과제는 2음절부터 6음절까지의 비단어가 각 4 개씩 총 20 개 문항으로 구성되어 있으며, 정확하 게 산출한 음절별로 점수를 부여하여 총점은 80 점으로 하였다.

2.2.2.2. 숫자 거꾸로 회상하기

연구 대상 아동들의 음운작업기억을 평가하기 위한 과제로 서, 선행연구(Yim et al., 2015)에서 사용한 순행 회상 과제를 역 행 방식으로 변경하여 사용하였다. 검사자는 아동에게 1 부터 9 까지의 숫자 중 일련의 목록이 녹음된 음성파일을 들려주고, 아 동이 이를 듣고 숫자의 목록을 거꾸로 회상하여 산출하도록 지 시하였다. 1 단계인 숫자 2 개부터 6 단계인 숫자 7 개까지의 숫자 목록이 각 2 개씩 총 12 개의 문항으로 구성되어 있으며, 아동이 해당 문항의 모든 숫자를 정확하게 역행 회상하는 경우 문항점 수 1 점을, 그렇지 않은 경우 0 점을 부여하였다. 과제 실시 전 1 부터 9 까지의 숫자를 아직 습득하지 못한 아동은 실험에서 제 외하여, 모든 아동들이 동일한 회상 부담 조건에서 과제를 수행 하도록 하였다.

\subsection{3. 언어 능력 평가}

2.2.3.1. 수용 및 표현어휘력

본 연구에 참여한 일반아동 집단과 언어발달지연 아동 집단 의 어휘력을 평가하기 위하여 수용 및 표현 어휘력 검사 (Receptive and Expressive Vocabulary Test, Kim et al., 2009)를 실 시하였다. 이 검사는 만 2 세 6 개월의 유아부터 16 세까지의 청소 년의 어휘 능력을 측정할 수 있는 표준화된 검사도구로서, 그림 및 목표어휘 노출 효과를 배제하기 위하여 표현어휘 검사를 먼 저 실시한다. 지침서에 따라 표현어휘 검사는 검사자가 아동에 게 그림을 제시하고 그에 해당하는 목표어휘를 산출하도록 지 시하는 방식으로 진행되었으며, 수용어휘 검사는 4개의 그림을 동시에 보여주면서 검사자가 말하는 어휘에 해당하는 그림을 아동이 고르게 하였다. 지침서에서 설정한 기초선과 한계선 규 정에 따라 각 아동들의 수용 및 표현어휘력 검사를 실시하였으 며, 본 연구의 분석에는 원점수를 사용하였다.

\subsubsection{2. 문법성 판단}

아동들의 문법형태소 인식 능력을 평가하기 위하여 선행연 구(Yim et al., 2015)에서 사용한 문법성 판단 과제를 실시하였 다. 아동들에게 15 개의 정문과 15 개의 비문을 들려주고 문장의 정오 여부를 판단하게 하는 과제로, 모든 문항은 3 어절의 문장으 로 구성되어 있다. 연구대상 아동들에게는 Microsoft Powerpoint
로 제작된 그림 자료와 함께 3 어절 문장의 녹음파일이 동시에 제시되었으며, 아동들이 문장을 듣고 조사의 적정성 여부를 탐 지하여 문장의 정오 여부를 정확하게 판단한 경우 1 점, 그렇지 않은 경우 0 점을 부여하였다.

\section{3. 자료분석 및 신뢰도}

본 연구의 분석에 사용되는 자료의 신뢰도 검증을 위해 언어 재활사 1 급 자격증을 소지한 언어병리학과 박사과정의 연구자 1 인이 모든 자료들의 $10 \%$ 를 무작위 추출하여 재검사를 실시하 였으며, 그 결과 일치도는 $98.86 \%$ 로 나타났다. 자료분석에는 SPSS 19.0 프로그램을 사용하였으며, 집단 간 음운인식 과제의 수행력 차이를 검토하기 위하여 일원분산분석을 실시하였다. 음운인식 과제들과 음운처리 및 언어능력 과제 간의 상관관계 를 분석하기 위하여 Pearson 상관계수를 산출하였으며, 단계적 중다회귀분석(stepwise multiple regression)을 통해 집단별로 언 어능력을 유의하게 예측하는 음운인식 과제가 무엇인지 검토 하였다.

\section{3. 연구 결과}

\section{1. 집단 간 음운인식 과제 수행력 차이}

집단 간 음운인식 과제의 수행력 차이를 검증하기 위해 일원 분산분석을 실시하였으며, 그 결과는 표 2에 제시하였다. 집단 을 독립변수로 한 일원분산분석 결과, 음절수세기 과제를 제외 한 음절탈락 $[F(1,31)=10.425, p=.003]$ 과 음절변별 $[F(1,31)=5.455$, $p=.026]$ 과제에서의 집단 간 차이가 유의하였다. 즉, 일반아동 집 단의 음절탈락과 음절변별 과제의 수행력이 언어발달지연 아동 집단에 비해 유의하게 높았으며, 음절수세기 과제는 집단 간 수 행력에 통계적으로 유의한 차이가 없었다.

표 2. 집단 간 음운인식 과제 수행력에 대한 기술통계 및 일원분산분석 결과

Table 2. Descriptive statistics and one-way ANOVA results on accuracy of phonological awareness tasks between groups

\begin{tabular}{c|c|c|c|c}
\hline & $\mathrm{TD}(\mathrm{n}=18)$ & $\mathrm{LD}(\mathrm{n}=15)$ & \multirow{2}{*}{$F$-value } & $p$-value \\
\cline { 2 - 3 } & $\mathrm{M}(S D)$ & $\mathrm{M}(S D)$ & .891 & .352 \\
\hline $\begin{array}{c}\text { Syllable } \\
\text { counting }\end{array}$ & $8.47(2.10)$ & $9.06(1.47)$ & .003 \\
\hline $\begin{array}{c}\text { Syllable } \\
\text { deletion }\end{array}$ & $4.20(3.73)$ & $7.67(2.40)$ & 10.425 & .003 \\
\hline $\begin{array}{c}\text { Syllable } \\
\text { categorization }\end{array}$ & $2.73(3.11)$ & $5.22(3.00)$ & 5.455 & .026 \\
\hline
\end{tabular}

3.2. 집단 간 음운인식 과제와 음운처리 및 언어능력 과제 간 상관관계 차이

집단별로 음운인식 과제들과 음운처리 과제 및 언어능력 과 제 간 상관관계를 분석하기 위하여 각 과제들의 정반응률에 대 한 Pearson 상관계수를 산출하였으며, 각 과제에 대한 기술통계 결과는 표 3 에, 상관분석 결과는 표 4 에 제시하였다. 일반아동 
집단은 음절탈락 과제와 숫자 거꾸로 회상하기 과제 $(r=556$, $p=.020)$, 음절변별 과제와 수용어휘력 $(r=.566, p=.014)$ 간 상관 관계가 유의하였으며, 음절수세기 과제와 유의한 상관관계를 보인 음운처리 및 언어능력 과제는 없었다. 언어발달지연 아동 집단은 음절수세기 과제와 숫자 거꾸로 회상하기 $(r=.639, p=.028)$, 수용어휘력 $(r=.639, p=.010)$, 표현어휘력 $(r=.651, p=.009)$, 그리 고 문법성판단 과제 $(r=.646, p=.009)$ 간의 상관관계가 유의하였 으며, 음절탈락 및 음절변별 과제와 유의한 상관관계를 보인 음 운처리 및 언어능력 과제는 없었다.

표 3. 집단별 음운처리 과제 및 언어능력 과제에 대한 기술통계 결과 Table 3. Descriptive statistics of tasks by groups

\begin{tabular}{c|c|c}
\hline \multirow{2}{*}{ Task } & TD $(\mathrm{n}=18)$ & $\mathrm{LD}(\mathrm{n}=15)$ \\
\cline { 2 - 3 } & $\mathrm{M}(S D)$ & $\mathrm{M}(S D)$ \\
\hline NWR & $47.56(11.36)$ & $43.07(13.59)$ \\
\hline Digit backward & $2.82(1.86)$ & $1.50(1.02)$ \\
\hline REVT-R & $68.61(10.34)$ & $55.60(15.20)$ \\
\hline REVT-E & $72.33(10.66)$ & $62.60(15.18)$ \\
\hline GJT & $21.61(5.87)$ & $18.33(4.67)$ \\
\hline
\end{tabular}

$\mathrm{TD}$, typically developing children; LD, children with language delay; NWR, nonword repetition; REVT-R, receptive \& expressive vocabulary test-receptive (Kim et al., 2009); REVT-E, receptive \& expressive vocabulary test-expressive (Kim et al., 2009); GJT, grammaticality judgement task.

표 4. 집단별 음운인식 과제와 음운처리 및 언어능력 과제 간 상관관계 분석 결과

Table 4. The correlation coefficient among tasks by groups

\begin{tabular}{c|c|c|c|c}
\hline \multirow{2}{*}{ Group } & Tasks & $\begin{array}{c}\text { Syllable } \\
\text { counting }\end{array}$ & $\begin{array}{c}\text { Syllable } \\
\text { deletion }\end{array}$ & $\begin{array}{c}\text { Syllable } \\
\text { categorization }\end{array}$ \\
\hline \multirow{4}{*}{$\begin{array}{c}\text { TD } \\
(n=18)\end{array}$} & NWR & .402 & .441 & .233 \\
\cline { 2 - 5 } & Digit backward & .472 & $.556^{*}$ & .390 \\
\cline { 2 - 5 } & REVT-R & .291 & .291 & $.566^{*}$ \\
\cline { 2 - 5 } & REVT-E & .205 & .446 & .428 \\
\cline { 2 - 5 } & GJT & .105 & .387 & $.513^{*}$ \\
\hline \multirow{4}{*}{$\begin{array}{c}\text { LD } \\
(n=15)\end{array}$} & NWR & .217 & .191 & .121 \\
\cline { 2 - 5 } & Digit backward & $.584^{*}$ & .235 & .029 \\
\cline { 2 - 5 } & REVT-R & $.639^{*}$ & .352 & .329 \\
\cline { 2 - 5 } & REVT-E & $.651^{* *}$ & .224 & .263 \\
\cline { 2 - 5 } & GJT & $.646^{* *}$ & .078 & .115 \\
\hline
\end{tabular}

TD, typically developing children; $\mathrm{LD}$, children with language delay; NWR, nonword repetition; REVT-R, receptive \& expressive vocabulary test-receptive (Kim et al., 2009); REVT-E, receptive \& expressive vocabulary test-expressive (Kim et al., 2009); GJT, Grammaticality Judgement Task. ${ }^{*} p<.05,{ }^{* *} p<.01$.

\section{3. 집단별 언어능력을 예측하는 음운인식 과제}

집단별로 언어능력을 예측하는 음운인식 과제가 무엇인지 검토하기 위하여 수용 및 표현어휘력 점수와 문법성판단 점수 를 종속변수로 하여 각 집단별로 단계적 중다회귀분석을 실시 하였다. 모든 회귀식에 대하여 Durbin-Watson 값을 산출, 잔차 의 독립성 조건을 충족시키는 것을 확인하였다. 회귀분석 결과 는 표 5 에 제시하였다.

먼저 일반아동 집단의 경우 수용어휘력 점수를 유의하게 예
측하는 과제는 음절변별이었으며 $[F(1,16)=7.548, p=.014]$, 음절 변별 과제의 수행력이 수용어휘력 수행력 분산의 약 $32.1 \%$ (수 정결정계수는 약 $27.8 \%$ )를 설명하는 것으로 나타났다. 또한 일 반아동 집단의 문법성판단 점수를 유의하게 예측하는 과제도 음절변별인 것으로 나타났으며 $[F(1,16)=5.700, p=.030]$, 음절변 별 과제의 수행력이 문법성판단 수행력 분산의 약 $26.3 \%$ (수정 결정계수는 약 $21.7 \%$ )를 설명하는 것으로 나타났다. 일반아동 집단의 표현어휘력 점수를 유의하게 예측하는 음운인식 과제 는 없었다.

언어발달지연 아동 집단의 경우 수용어휘력 점수를 유의하 게 예측하는 과제는 음절수세기였으며 $[F(1,13)=8.994, p=.010]$, 음절수세기 과제가 수용어휘력 수행력 분산의 약 $40.9 \%$ (수정결 정계수는 약 $36.3 \%$ )를 설명하는 것으로 나타났다. 또한 언어발 달지연 아동 집단의 표현어휘력 점수를 유의하게 예측하는 과 제도 수용어휘력과 마찬가지로 음절수세기 과제였으며 $[F(1$, 13 ) $=9.586, p=.009]$, 표현어휘력 수행력 분산의 약 $42.4 \%$ (수정결 정계수는 약 $38.0 \%$ )를 설명하는 것으로 나타났다. 마지막으로 언어발달지연 아동 집단의 문법성판단 점수를 유의하게 예측해 주는 과제도 음절수세기인 것으로 나타났으며 $[F(1,13)=9.302$, $p=.009]$, 문법성판단 점수는 언어발달지연 아동 집단의 문법성 판단 수행력 분산의 약 $41.7 \%$ (수정계수는 약 $37.2 \%$ )를 설명하 는 것으로 나타났다.

표 5. 집단별 음운인식 과제와 언어능력 과제 간 회귀분석 결과 Table 5. Results of stepwise multiple regression analysis by groups

\begin{tabular}{c|c|c|c|c|c|c|c}
\hline \multicolumn{2}{l}{} & Predictor & $\begin{array}{c}\text { Unstan } \\
\text { dar- } \\
\text { dized } \beta\end{array}$ & SE & $\begin{array}{c}\text { Standar } \\
\operatorname{dized} \beta\end{array}$ & $\begin{array}{c}R^{2} \\
\text { (adjusted } \\
R^{2}\end{array}$ & $\begin{array}{c}p- \\
\text { value }\end{array}$ \\
\hline \multirow{4}{*}{$\begin{array}{c}\text { TD } \\
(\mathrm{n}=18)\end{array}$} & REVT-R & $\begin{array}{c}\text { Syllable } \\
\text { categorization }\end{array}$ & 1.950 & .710 & .566 & $\begin{array}{c}.321 \\
(.278)\end{array}$ & .014 \\
\cline { 2 - 8 } & REVT-E & - & - & - & - & - & - \\
\hline \multirow{4}{*}{$\begin{array}{c}\text { LD } \\
(n=15)\end{array}$} & GJT & $\begin{array}{c}\text { Syllable } \\
\text { categorization }\end{array}$ & 1.003 & .420 & .513 & $\begin{array}{c}.263 \\
(.217)\end{array}$ & .030 \\
\cline { 2 - 8 } & REVT-R & $\begin{array}{c}\text { Syllable } \\
\text { counting }\end{array}$ & 4.630 & 1.544 & .639 & $\begin{array}{c}.409 \\
(.363)\end{array}$ & .010 \\
\cline { 2 - 8 } & REVT-E & $\begin{array}{c}\text { Syllable } \\
\text { counting }\end{array}$ & 4.711 & 1.521 & .651 & $\begin{array}{c}.424 \\
(.380)\end{array}$ & .009 \\
\hline
\end{tabular}

$\overline{\mathrm{TD}}$, typically developing children; LD, children with language delay; REVT-R, receptive \& expressive vocabulary test-receptive (Kim et al., 2009); REVT-E, receptive \& expressive vocabulary test- expressive (Kim et al., 2009); GJT, grammaticality judgement task.

\section{4. 논의 및 결론}

본 연구는 학령전기 언어발달지연 아동과 일반 아동의 음운 인식 능력과 음운처리 능력, 또 언어능력과의 관계를 살펴보고 자 하였다. 음소인식 능력은 6 세 이후에야 본격적으로 발달하 는 것으로 나타난 많은 선행연구 결과들을 근거로(Dodd \& Gillon, 2001; Hong et al., 2007; Liberman et al., 1974; Shin et al., 2009), 4 6세 아동을 대상으로 한 본 연구에서는 음절 수준의 
과제만을 연구도구로 사용하였다. 연구 결과, 음절수세기를 제 외한 음운인식 과제 수행력에서 집단 간 유의한 차이를 확인할 수 있었다. 또한 일반아동은 음절탈락 과제와 숫자 거꾸로 회상 하기 과제, 음절변별 과제와 수용어휘력 간 유의한 상관관계가 있었으며, 언어발달지연 아동은 음절수세기 과제와 숫자 거꾸 로 회상하기, 표현어휘력, 문법성판단 과제 간 유의한 상관관계 가 있었다. 집단별로 아동들의 언어능력을 예측하는 음운인식 과제로는, 일반아동 집단의 경우에는 음절변별 과제가 수용어 휘력과 문법성판단 과제 수행력을 유의하게 예측해주었으며, 언어발달지연 아동 집단은 음절수세기 과제가 수용 및 표현 어 휘력, 문법성판단 과제 수행력을 유의하게 예측하였다.

본 연구에서는 음절수준의 음운인식 과제에 대한 집단 간 수 행력을 비교하였는데, 언어발달장애 아동들의 음운인식 능력 이 또래 일반아동들에 비해 낮음을 밝힌 선행연구들과 같이 (Bird et al., 1995; Frith, 1985; Juel, 1988; Owen \& Leonard, 2002; Rvachew et al., 2003; Shin et al., 2006) 본 연구에서도 언어발달 지연 아동들의 음운인식 과제 수행력이 또래 일반아동 집단에 비해 낮게 나타났다. 다만 음절수세기 과제는 집단 간 차이가 유의하지 않았는데, 이는 10 점 만점인 과제에 대한 일반아동 집 단의 과제 수행력 평균이 9.06점 $(S D=1.47)$, 언어발달지연 아동 집단의 평균이 8.47 점 $(S D=2.10)$ 으로 두 집단 모두 높게 나타난 결과로 볼 때, 음절수세기의 경우 4 6세 아동들이 언어발달지 연 여부에 관계없이 과제 수행이 천장효과(ceiling effect)를 보였 기 때문인 것으로 판단된다.

즉, 한국어를 사용하는 아동들은 4 6세에는 낱말들을 음절 로 분절하여 인지하는 능력이 보편적으로 발달하는 것으로 간 주할 수 있는데, 이는 한국어의 특징을 그 이유로 생각해볼 수 있다. 한국어는 구어의 음절 경계가 명확한 언어(syllable-timed language)로서(Kim, 2007; Kim, 2008), 글자를 쓸 때에도 영어처 럼 하나의 음절을 구성하고 있는 각 자소(grapheme)가 병렬적으 로 나열되는 것이 아닌, 2 4개의 자소가 하나로 조합되어 음절 단위로 배열된다(Park et al., 2000). 따라서 말소리의 연쇄를 음 절 단위로 분절할 수 있는 능력은 음절 단위가 중요한 한국어의 구어 의사소통에 있어서 필수적으로 전제되어야 하는 능력이 므로, 다른 음절단위의 음운인식 과제보다 이른 시기에 발달하 는 것으로 판단된다.

본 연구에서는 음운인식 과제와 기타 음운처리 과제, 언어능 력 과제 간의 상관관계를 검토하였는데, 일반아동 집단의 경우 음절수세기 과제와 유의한 상관관계가 나타난 연구과제는 없 었으며, 음절탈락 과제와 숫자 거꾸로 회상하기 과제, 그리고 음절변별 과제와 수용어휘력 간에 유의한 상관관계가 나타났 다. 일반적으로 숫자 거꾸로 회상하기 과제는 비단어 따라말하 기 과제와 함께 학령전기 아동들의 음운작업기억을 측정하는 과제로 많은 선행연구들에서 사용되는데(Adams \& Gathercole, 1995; Farquharson et al., 2018; Munson et al., 2005; Speidel, 1993), 비단어 따라말하기 과제는 무의미음절로 구성된 일련의 비단 어를 자극물이 제시된 순서대로 회상 산출하는 과제이며, 숫자 거꾸로 회상하기 과제는 일련의 숫자 목록을 제시된 순서와 반
대로 회상하는 역행 산출 과제이다. 비단어 따라말하기 과제는 순행 과제로서 음운정보를 조작하는 과정이 부재함을 이유로 음운단기기억(phonological short-term memory)을 측정하는 과제 인 것으로 주장하기도 하는데(Gathercole \& Baddeley, 1989), 본 연구에서도 두 과제가 음운인식 과제와 서로 다른 상관관계를 보인 바, 각 과제가 서로 다른 음운처리 능력을 측정하는 과제 라는 선행연구들의 견해를 따르기로 한다. 비단어 따라말하기 과제는 음운단기기억을 측정하는 과제로, 숫자 거꾸로 회상하 기 과제는 음운작업기억을 측정하는 과제라고 정의했을 때, 음 절탈락 과제는 음운단기기억 과제와는 유의한 상관관계를 보 이지 않았으나 음운작업기억 과제와는 유의한 상관관계를 보 였다. 본 연구에서 사용한 음절탈락 과제는 제시된 낱말들을 듣 고 각 낱말의 첫음절 또는 끝음절을 제거한 나머지 음절들을 산 출해내는 과제이다. 이 과제를 수행하기 위해서는, 제시된 2 3 음절의 낱말을 듣고, 청각정보를 일시적으로 저장하고 처리하 는 장치인 음운루프(phonological loop)에 잠시 저장한 후, 검사 자의 지시에 따라 가장 첫 음절이나 가장 마지막 음절을 탈락시 키는 과정을 거쳐 나머지 음절들만을 구어로 산출해내야 한다. 다시 말해, 낱말을 청각적으로 저장하고 조작하는 과정이 동시 에 수행되는 과제인데, 이는 숫자 거꾸로 회상하기와 같이 음운 루프에서 수행되는 작업기억의 처리 과정과 일치한다. 따라서 두 과제 간 정적인 상관관계가 나타난 것은 합리적인 결과라고 생각된다.

한편 수용어휘력과는 음절변별 과제가 유의한 정적 상관관 계를 보였는데, 음절변별 과제는 3 개의 낱말 목록을 듣고, 첫소 리 혹은 끝소리가 다른 낱말을 찾아 구어로 답하는 과제로서, 음절탈락 과제에 비해 장기기억이 보다 적극적으로 개입되는 과제라고 할 수 있다. 음절탈락 과제는 하나의 낱말만을 자극으 로 제시하므로 낱말들을 음절 단위로 분절시켜서 기억했다가 일종의 비단어 형태로 산출하는 과제라면, 음절변별 과제는 3 개의 낱말을 모두 음운루프에 저장했다가 첫음절이나 끝음절 이 다른 목표어휘 하나를 골라 해당 낱말을 산출해야 하는 과제 이다. 따라서 자극물인 낱말들이 연구대상 아동들의 어휘집에 저장되어 있고, 또 그 세 개 낱말 목록의 음운표상(phonological representation)들이 완전하고 안정적일수록 과제의 수행이 용이 해진다. 수용어휘력 검사는 주어지는 청각적 자극물을 듣고 음 운정보로 부호화한 후 네 개의 그림들을 해독하여 어휘집이라 는 장기기억의 정보를 끌어와 자극물과 일치하는 그림을 고르 는 과정으로 진행된다. 따라서 아동의 어휘집이 크고, 개별 어 휘들의 음운표상과 의미표상이 완전하고 안정적일수록 과제의 수행력이 높아진다. 음절변별 과제와 수용어휘력 검사는 모두 동시에 제시된 복수의 낱말들에 대한 처리를 요하는 검사로서, 피험자의 어휘집의 크기와 목표 어휘들의 음운표상의 질을 전 제로 한다는 점이 두 과제가 정적인 상관관계를 보이는 근거가 될 수 있을 것으로 생각된다.

일반아동 집단과 달리 언어발달지연 아동 집단의 경우 음절 수세기 과제만이 비단어 따라말하기 과제를 제외한 다른 과제 들과 유의한 상관관계를 보였다. 이는, 기술통계 결과를 살펴보 
면 언어발달지연 아동 집단은 평균점수가 10 점 만점인 음절탈 락과 음절변별 과제의 평균점수가 모두 5점미만으로서 우연수 준(chance level) 미만의 수행력을 보여, 이 두 과제에 대한 정오 반응 여부를 통계적으로 유의미하게 판단할 수 없었기 때문인 것으로 보인다. 언어발달지연 아동 집단의 경우 한국어 말소리 를 해석하기 위한 기초적인 음운인식 능력이라고 할 수 있는 음 절수세기 과제와 다른 과제들과의 상관관계가 유의한 것으로 나타났는데, 비단어 따라말하기 과제만이 그렇지 않았다. 모든 과제들과 비단어 따라말하기 과제의 차이점은, 다른 과제들은 자극물들이 모두 실제단어로 구성되어 있지만, 비단어 따라말 하기는 무의미음절의 연속체로서 한국어 단어와의 유사성이 없는 낱말 형태의 자극물이라는 점이다. 따라서 언어발달지연 아동들의 경우 음절수세기, 숫자 거꾸로 회상하기, 수용 및 표 현어휘력, 문법성판단 과제를 수행할 때 장기기억이 영향을 미 쳤을 가능성을 생각해볼 수 있다. 비단어 따라말하기 과제 외 나머지 각 과제를 수행하기 위해서는 음운처리능력 외에 아동 의 어휘집, 구문능력이나 형태소 지식 등의 장기기억이 활용될 수 있다. 따라서 본 연구의 결과는 연구에 참여한 언어발달지연 아동들이, 다양한 과제를 수행할 때 음운처리능력을 충분히 활 용하고 있지 않을 가능성을 시사한다.

마지막으로, 집단별로 언어능력을 예측하는 음운인식 과제 를 검토했을 때에도 두 집단이 서로 다른 특징을 보였다. 일반 아동 집단은 음절변별 과제의 수행력이 수용어휘력 수행력 분 산의 약 $32.1 \%$ (수정결정계수는 약 $27.8 \%$ ), 문법성판단 과제 수 행력 분산의 약 $26.3 \%$ (수정결정계수는 약 $21.7 \%$ )를 유의하게 설명해주는 것으로 나타났는데, 이러한 결과는 앞에서 지적했 던 것처럼 음절변별 과제의 특징을 통해 설명할 수 있다. 음절 변별 과제는 음절탈락 과제에 비교했을 때 장기기억이 활용될 여지가 높은 과제이며, 따라서 음절변별 과제의 수행력이 다른 두 언어능력 과제를 예측한 것은 합리적이다. 특징적인 것은, 표현어휘력의 경우 유의한 예측변수가 나타나지 않은 점인데, 이는 표현어휘력 검사와 수용어휘력 검사의 차이점으로 설명 해볼 수 있다. 표현어휘력 검사는 제시되는 그림을 보고 그림의 이름을 정확하게 명명해야 하는 검사이며, 수용어휘력 검사는 네 개의 보기들 가운데에서 검사자가 구어로 제시하는 낱말을 연결시켜야 하는 검사이다. 따라서 수용어휘력 검사를 수행할 때 아동들은 검사자가 제시한 구어 자극물에 대한 수용어휘가 명확히 정립되어 있지 않더라도, 나머지 낱말들이 어휘집에 있 다면 상호배타성 가정을 통해 목표 그림을 골라내 정반응 할 수 있다. 이는 청각적으로 제시된 목표어휘와 시각적으로 제시된 그림들 중 배타적으로 제거하고 남은 하나의 그림을 임의적으 로 연결한 것이며, 따라서 수용어휘력 검사는 표현어휘력 검사 에 비해 단어의 임의성에 대한 인식이 활용될 여지가 높은 과제 라고 할 수 있다. 단어의 임의성 대한 인식은 의미론 영역에서 의 상위언어인식 능력으로서, 참조물(Referent)과 거기에 붙여 진 단어, 즉 음운론적 지시어 간의 임의적인 관계를 인지하는 능력을 의미한다(Bowey \& Tunmer, 1984). 그러므로 일반아동 집단에서 음운론 영역에서의 상위언어인식 능력인 음운인식
과제가 수용어휘력과 문법성판단 과제 수행력을 예측한 본 연 구의 결과는 논리적으로 타당하며, 상위언어인식 능력 발달에 서 음운론 영역의 중요성을 확인한 결과라고 할 수 있다.

일반아동 집단과는 달리 언어발달지연 아동 집단은 음절수 세기 과제의 수행력이 수용어휘력의 약 $40.9 \%$ (수정결정계수는 약 $36.3 \%$ ), 표현어휘력의 약 $42.4 \%$ (수정결정계수는 약 $38.0 \%$ ), 문법성판단 과제 수행력의 약 $41.7 \%$ (수정결정계수는 약 $37.2 \%$ ) 를 유의하게 설명하였다. 다른 두 음운인식 과제가 예측변수로 나타나지 않은 것은, 앞에서 지적한 바와 같이 기술통계 결과로 판단할 수 있는 이 집단의 음운인식 능력 미발달을 그 이유로 생각해볼 수 있을 것이다. 그러나 한국어 말소리를 음절 단위로 인식할 수 있는 능력은 일반아동 집단과 마찬가지로 충분히 발 달했다고 볼 수 있으며, 이러한 과제가 수용 및 표현어휘력, 문 법성판단 과제의 수행력을 유의하게 예측한 점에서 이 집단의 해당 음운인식 능력의 중요성을 확인할 수 있다. 임상에서 언어 발달지연 아동의 음절수세기 능력을 주의 깊게 살필 필요가 있 을 것으로 보이며, 특히나 이 능력은 집단 간 차이가 유의하지 않은 것으로 나타난 바, 음절수세기에 어려움을 보이는 아동은 특별한 주의를 요하는 임상군으로 보아야 할 것이다. 그런데 상 관관계 분석에서 나타난 것와 같이 언어발달지연 아동 집단은 과제 수행 시 아동들이 갖고 있는 음운인식 능력을 충분히 활용 하기보다는 장기기억에 의존할 가능성이 있으므로, 장기기억 을 확장시켜주는 중재로써 이 아동들이 가진 강점을 공고하게 해줌과 동시에, 상위언어인식 능력을 자극하는 중재를 통해 아 동들의 잠재력을 촉진할 필요가 있을 것으로 보인다.

본 연구는 음운론 영역에서의 상위언어인식 능력인 음운인 식 능력과 다른 언어능력 간의 관계를 일반아동과 언어발달지 연 아동 집단별로 비교 검토하였다. 두 집단은 음운인식 능력과 그 능력을 활용하는 측면에서 뚜렷한 차이를 보였으며, 따라서 임상 현장이나 유아교육 현장에서 이들 아동들을 중재 및 교육 할 때 각 집단의 특징을 정확히 인식하고 음운인식 능력에 대한 적절한 개입이 이루어져야 할 것이다. 본 연구는 일반아동 18 명, 언어발달지연 아동 15 명을 대상으로 한 바, 연구의 일반화를 공 고히 하기 위해 표본의 크기를 확대한 후속연구가 필요할 것으 로 보인다. 또한 후속연구에서는 조작해야 하는 음운인식의 단 위 및 위치 등을 다양하게 구성하여 음운인식 능력을 보다 상세 하게 검토하고, 의미론, 구문 및 형태론, 화용론 영역에서의 상 위언어인식 능력과의 관계를 체계적으로 분석하여 학령전기 아동들의 상위언어능력을 면밀히 살핌으로써 임상 및 교육 현 장에 기여할 수 있기를 제언한다.

\section{References}

Adams, A. M., \& Gathercole, S. E. (1995). Phonological working memory and speech production in preschool children. Journal of Speech and Hearing Research, 38(2), 403-414.

Ahn, S. W., Heo, M. J., Kim, Y., \& Kim, M. K. (2011). Development of Phonological Awareness in Korean Children Aged between 4- 
7 throughout Korea. Journal of Speech \& Hearing Disorders, 20(3), 121-141.

Anthony, J. L., Lonigan, C. J., Burgess, S. R., Driscoll, K., Phillips, B. M., \& Cantor, B. G. (2002). Structure of preschool phonological sensitivity: Overlapping sensitivity to rhyme, words, syllables, and phonemes. Journal of Experimental Child Psychology, 82(1), 65-92.

Bird, J., Bishop, D. V., \& Freeman, N. H. (1995). Phonological awareness and literacy development in children with expressive phonological impairments. Journal of Speech, Language, and Hearing Research, 38(2), 446-462.

Bowey, J. A., Grieve, R., Herriman, M., Myhill, M., Nesdale, A., Pratt, C., \& Tunmer, W. E. (1984). Word awareness in children. In W. E. Tunmer, C. Pratt, \& M. L. Herriman (Eds.), Metalintuistic awareness in children: Theory, research, and implications (pp. 73-91). Berlin, Germany: Springer-Verlag.

Bruck, M. (1992). Persistence of dyslexics' phonological awareness deficits. Developmental Psychology, 28(5), 874-886.

Bus, A. G., \& van IJzendoorn, M. H. (1999). Phonological awareness and early reading: A meta-analysis of experimental training studies. Journal of Educational Psychology, 91(3), 403-414.

Catts, H. W. (1993). The relationship between speech-language impairments and reading disabilities. Journal of Speech, Language, and Hearing Research, 36(5), 948-958.

Chaney, C. (1992). Language development, metalinguistic skills, and print awareness in 3-year-old children. Applied Psycholinguistics, 13(4), 485-514.

Dodd, B., \& Gillon, G. (2001). Exploring the relationship between phonological awareness, speech impairment, and literacy. Advances in Speech Language Pathology, 3(2), 139-147.

Dixon, L.Q. (2010). The importance of phonological awareness for the development of early English reading skills among bilingual Singaporean Kindergartners. International Journal of Bilingual Education and Bilingualism, 13(6), 723-738.

Ehri, L. C., Nunes, S. R., Willows, D. M., Schuster, B. V., Yaghoub-Zadeh, Z., \& Shanahan, T. (2001). Phonemic awareness instruction helps children learn to read: Evidence from the National Reading Panel's meta-analysis. Reading Research Quarterly, 36(3), 250-287.

Farquharson, K., Hogan, T. P., \& Bernthal, J. E. (2018). Working memory in school-age children with and without a persistent speech sound disorder. International Journal of Speech-Language Pathology, 20(4), 422-433.

Felton, R. H., \& Pepper, P. P. (1995). Early identification and intervention of phonological deficits in kindergarten and early elementary children at risk for reading disability. School Psychology Review, 24(3), 405-414.

Frith, U. (1985). Beneath the surface of developmental dyslexia. In K.
E. Patterson, J. C. Marshall, \& M. Coltheart (Eds.), Surface dyslexia (Vol. 8, pp. 301-330). Abingdon, UK: Routledge.

Gathercole, S. E., \& Baddeley, A. D. (1989). Evaluation of the role of phonological STM in the development of vocabulary in children: A longitudinal study. Journal of Memory and Language, 28(2), 200-213.

Gathercole, S. E., Willis, C., \& Baddeley, A. D. (1991). Differentiating phonological memory and awareness of rhyme: Reading and vocabulary development in children. British Journal of Psychology, 82, 387-406.

Gillon, G. T. (2000). The efficacy of phonological awareness intervention for children with spoken language impairment. Language, Speech, and Hearing Services in Schools, 31(2), 126-141.

Gillon, G., \& McNeill, B. (2009). Phonological awareness effective practices in assessment and intervention. ACQuiring Knowledge in Speech, Language and Hearing, 11(2), 72-76.

Hong, S. I., Jeon, S. I., Pae, S., \& Lee, I. (2002). Development of phonological awareness in Korean children. Communication Sciences \& Disorders, 7(1), 49-64.

Juel, C. (1988). Learning to read and write: A longitudinal study of 54 children from first through fourth grades. Journal of Educational Psychology, 80(4), 437-447.

Jung, I. K., Choi, S. Y., \& Ha, J. W. (2015). Internal awareness of phonological representation in children with speech sound disorders. Communication Sciences \& Disorders, 20(1), 48-59.

Kang, J. K., \& Kim, Y. T. (2007). Phonological awareness of preschool children with and without specific language impairment. Communication Sciences \& Disorders, 12(1), 32-51.

Kim, A. H., You, H. S., \& Kim, U. J. (2010). The relationship of phonological awareness, rapid naming, letter knowledge, shortterm memory, and working memory to Hangul word recognition abilities. Journal of Special Education, 45(1), 247-267.

Kim, J. L., Kang, E. H., \& Lee, J. Y. (2018). The effects of phonological awareness intervention program on the phonological awareness and word recognition ability in children with intellectual disabilities. Journal of Speech \& Hearing Disorders, 27(3), $1-12$.

Kim, J. Y., Kang, M. K., \& Kim, Y. T. (2019). The impact of phonological awareness and phonological working memory training on the reading disabilities of children during their early years of elementary school. Special Education Research, 18(2), 5-28.

Kim, M. B., \& Pae, S. Y. (2007). Word recognition and phonological awareness of kindergartener, second and fourth graders. Journal of Speech-Language \& Hearing Disorders, 16(2), 89-107.

Kim, S. J., \& Kim, Y. T. (2006). Development of phonological awareness abilities of normal children in the age of 5 and 6 through 
phonological elision task and its correlation to other phonological processing abilities. Communication Sciences \& Disorders, 11(3), 16-28.

Kim, S. J., Oh, G. A., Seo, E. Y., \& Ko, Y. K. (2018). Performance in a phonological deletion awareness task according to age and gender: Development of a phonological awareness screening test for preschool children. Phonetics and Speech Sciences, 10(2), 61-68.

Kim, Y. S. (2007). Phonological awareness and literacy skills in Korean: An examination of the unique role of body-coda units. Applied Psycholinguistics, 28(1), 69-94.

Kim, Y. S. (2008). The foundation of literacy skills in Korean: The relationship between letter-name knowledge and phonological awareness and their relative contribution to literacy skills. Reading and Writing, 22(8), 907-931.

Kim, Y. T., Hong, G. H., Kim, K. H., Jang, H. S., \& Lee, J. Y. (2009). Receptive \& expressive vocabulary test (REVT). Seoul, Korea: Seoul Community Rehabilitation Center.

Kim, Y. T., Sung, T. J., \& Lee, Y. K. (2011). Preschool receptiveexpressive language scale (PRES). Seoul, Korea: Seoul Community Rehabilitation Center.

Koa, Y. K., \& Kim, S. J. (2010). A comparison of phonological awareness and reading ability between children with and without functional articulatory and phonological disorders. Communication Sciences \& Disorders, 15(2), 157-167.

Lenchner, O., Gerber, M. M., \& Routh, D. K. (1990). Phonological awareness tasks as predictors of decoding ability: Beyond segmentation. Journal of Learning Disabilities, 23(4), 240-247.

Liberman, I. Y., Shankweiler, D., Fischer, F. W., \& Carter, B. (1974). Explicit syllable and phoneme segmentation in the young child. Journal of Experimental Child Psychology, 18(2), 201-212.

Lonigan, C. J., Burgess, S. R., \& Anthony, J. L. (2000). Development of emergent literacy and early reading skills in preschool children: Evidence from a latent-variable longitudinal study. Developmental Psychology, 36(5), 596-613.

Metsala, J. L., \& Walley, A. C. (1998). Spoken vocabulary growth and the segmental restructuring of lexical representations: Precursors to phonemic awareness and early reading ability. In J. L. Metsala \& L. C. Ehri (Eds.), Word recognition in beginning literacy (pp. 89-120). Mahwah, NJ: Erlbaum.

Moon, S. B., \& Byun, C. J. (2003). Korean Kaufman assessment battery for children $(K-A B C)$. Seoul, Korea: Hakjisa.

Munson, B., Edwards, J., \& Beckman, M. E. (2005). Relationships between nonword repetition accuracy and other measures of linguistic development in children with phonological disorders. Journal of Speech, Language, and Hearing Research, 48(1), 61-78.

Nathan, L., Stackhouse, J., Goulandris, N., \& Snowling, M. J. (2004).
The development of early literacy skills among children with speech difficulties. Journal of Speech, Language, and Hearing Research, 47(2), 377-391.

Owen, A. J., Dromi, E., \& Leonard, L. B. (2001). The phonology morphology interface in the speech of Hebrew-speaking children with specific language impairment. Journal of Communication Disorders, 34(4), 323-337.

Owen, A. J., \& Leonard, L. B. (2002). Lexical diversity in the spontaneous speech of children with specific language impairment. Journal of Speech, Language and Hearing Research, 45(5), 927-937.

Park, H. A. (2000). The development of phonological awareness in children. Korean Journal of Child Studies, 21(1), 35-44.

Plaza, M., \& Cohen, H. (2003). The interaction between phonological processing, syntactic awareness, and naming speed in the reading and spelling performance of first-grade children. Brain and Cognition, 53(2), 287-292.

Rvachew, S., Ohberg, A., Grawburg, M., \& Heyding, J. (2003). Phonological awareness and phonemic perception in 4-year-old children with delayed expressive phonology skills. American Journal of Speech-Language Pathology, 12(4), 463-471.

Schuele, C. M., \& Boudreau, D. (2008). Phonological awareness intervention: Beyond the basics. Language, Speech, and Hearing Services in Schools, 39(1), 3-20.

Shin, H. J., Park, H. J., \& Jang, H. J. (2009). The development of syllable and phonemic awareness abilities of children aged four, five, and six. Journal of Speech \& Hearing Disorders, 18(3), 99-114.

Shin, Y. J., Seo, Y. K., \& Ahn, S. W. (2006). A study of phonological awareness ability depending on level of children's language competence. Journal of Speech \& Hearing Disorders, 15(4), 91-113.

Smith-Lock, K. M. (1995). Morphological usage and awareness in children with and without specific language impairment. Annals of Dyslexia, 45(1), 161-185.

Snowling, M. (1998). Dyslexia as a phonological deficit: Evidence and implications. Child Psychology and Psychiatry Review, 3(1), 4-11.

Snowling, M., Bishop, D. V. M., \& Stothard, S. E. (2000). Is preschool language impairment a risk factor for dyslexia in adolescence? The Journal of Child Psychology and Psychiatry, 41(5), 587-600.

Speidel, G. E. (1993). Phonological short-term memory and individual differences in learning to speak: A bilingual case study. First Language, 13(37), 69-91.

Stanovich, K. E. (1992). Speculations on the causes and consequences of individual differences in early reading acquisition. In P. B. Gough, L. C. Ehri, \& R. Treiman (Eds.), Reading acquisition (pp. 307-342). Hillsdale, NJ: Erlbaum. 
Stark, R. E., \& Heinz, J. M.(1996). Vowel perception in children with and without language impairment. Journal of Speech and Hearing Rearch, 39(4), 860-869.

Swan, D., \& Goswami, U. (1997). Phonological awareness deficits in developmental dyslexia and the phonological representations hypothesis. Journal of Experimental Child Psychology, 66(1), $18-41$.

Tunmer, W. E., \& Grieve, R. (1984). Syntactic awareness in children. In W. E. Tunmer, C. Pratt, \& M. L. Herriman (Eds.), Metalintuistic awareness in children (pp. 92-104). Berlin, Germany: SpringerVerlag.

Tunmer, W. E., \& Herriman, M. L. (1984). The development of metalinguistic awareness: A conceptual overview. In W. E. Tunmer, C. Pratt, \& M. L. Herriman (Eds.), Metalintuistic awareness in children (pp. 12-35). Berlin, Germany: Springer- Verlag.

Tunmer, W. E., Herriman, M.. L., \& Nesdale, A. R. (1988). Metalinguistic abilities and beginning reading. Reading Research Quarterly, 23(2), 134-158.

Wagner, R. K., \& Torgesen, J. K. (1987). The nature of phonological processing and its causal role in the acquisition of reading skills. Psychological Bulletin, 101(2), 192-212.

Wagner, R. K., Torgesen, J. K., \& Rashotte, C. A. (1994). Development of reading-related phonological processing abilities: New evidence of bidirectional causality from a latent variable longitudinal study. Developmental Psychology, 30(1), 73-87.

Yang, Y., \& Pae, S. (2018). Korean first graders' word decoding skills, phonological awareness, rapid automatized naming, and letter knowledge with/without developmental dyslexia. Phonetics and Speech Sciences, 10(2), 51-60.

Yim, D., Kim, S., Yoo, J., Lee, Y., Lee, S., \& Chung, H. (2017). Diagnostic accuracy of working memory tasks depending on scoring unit and condition in preschool children. Communication Sciences \& Disorders, 22(3), 485-499.

Yim, D., Kim, S. Y., \& Yang, Y. (2015). Factor analysis of working memory tasks based on information processing characteristics: Predictive factors of receptive vocabulary and quick incidental learning in children with typically developing and receptive vocabulary delay. Communication Sciences \& Disorders, 20(2), 304-318.

Yim, D. S., Yang, Y. H., Jo, Y. J., Lee, J. Y., \& Seong, J. M. (2015). Grammatical meta-linguistic awareness and executive functioning skills in preschool-age children with and without specific language impairment. Journal of Speech \& Hearing Disorders, 24(4), 345-359.

Yopp, H. K. (1988). The validity and reliability of phonemic awareness tests. Reading Research Quarterly, 23(2), 159-177.

Ziegler, J. C., \& Goswami, U. (2005). Reading acquisition, developmental dyslexia, and skilled reading across languages: A psycholinguistic grain size theory. Psychological Bulletin, 131(1), 3-29.

\section{- 김신영 (Shinyoung Kim)}

이화여자대학교 언어병리학과 박사과정

서울시 서대문구 이화여대길 52

Tel: $02-3277-2120$

Email: sundaysky@ewhain.net 관심분야: 아동언어발달

\section{- 손진경 (Jinkyeong Son)}

이화여자대학교 언어병리학과 석사과정

서울시 서대문구 이화여대길 52

Tel: 02-3277-2120

Email: 172shg21@ewha.ac.kr

관심분야: 아동언어발달

- 임동선 (Dongsun Yim) 교신저자

이화여자대학교 언어병리학과 교수

서울시 서대문구 이화여대길 52

Tel: 02-3277-6720

Email: sunyim@ewha.ac.kr

관심분야: 아동언어발달, 이중언어 


\title{
4 6세 일반아동 및 언어발달지연 아동의 음운인식 및 음운처리 능력이 언어 능력에 미치는 영향*
}

\author{
김 신 영·손 진 경·임 동 선 \\ 이화여자대학교 언어병리학과
}

\begin{abstract}
국문초록
음운인식은 음운론 영역의 상위언어인식 능력으로, 읽기 및 어휘력 등의 언어능력을 예측하는 것으로 알려져 있 다. 본 연구는 음운인식 능력과 기타 음운처리 능력, 그리고 언어능력 간의 관계를 일반아동 집단과 언어발달지연 아동 집단 간 비교를 통해 살펴보고자 하였다. $4 \sim 6$ 세의 언어발달지연 아동 $(\mathrm{n}=15)$ 과 일반아동 $(\mathrm{n}=18)$ 을 대상으로 음 운인식 능력을 평가하기 위하여 음절수세기, 음절탈락, 음절변별 과제를 실시하였다. 또한 비단어 따라말하기, 숫 자 거꾸로 회상하기의 두 가지 음운처리 과제와 수용 및 표현어휘력, 문법성판단 과제와의 상관관계를 분석하고, 언어능력을 예측하는 음운인식 하위과제가 무엇인지 검토하였다. 음운인식 하위과제 중 음절수세기를 제외한 음 절탈락, 음절변별 과제 수행력의 집단 간 차이가 유의하였다. 또한 일반아동 집단은 음절탈락과 숫자 거꾸로 회상 하기, 음절변별과 수용어휘력 과제 수행력 간 상관관계가 유의하였으며, 언어발달지연 아동 집단은 음절수세기 과 제와 숫자 거꾸로 회상하기, 수용어휘력, 표현어휘력, 문법성판단 과제의 수행력 간 상관관계가 유의하였다. 그리 고 단계적 중다회귀분석 결과 일반아동 집단은 음절변별 과제가 수용어휘력 및 문법성판단 과제 수행력을 유의하 게 예측하는 것으로 나타났으며, 언어발달지연 아동 집단은 음절수세기 과제가 수용어휘력, 표현어휘력, 문법성판 단 과제 수행력을 유의하게 예측하는 것으로 나타났다. 언어발달지연 아동 집단은 일반아동 집단에 비해 음절수세 기를 제외한 나머지 음절 수준의 음운인식 과제의 수행력이 저조하였으며, 이러한 특징이 상관관계 분석 및 회귀 분석 결과에도 반영되었다. 또한 각 집단에서 음운인식 과제 수행력이 언어능력을 유의하게 예측하는 것으로 나타 난 결과는 음운론 영역의 상위언어인식 능력의 중요성을 시사한다.
\end{abstract}

핵심어: 음운인식, 음운처리, 상위언어인식, 어휘력, 문법성판단

\section{참고문헌}

강진경, 김영태 (2007). 취학전 단순언어장애 아동의 음운인식에 관한 연구. Communication Sciences \& Disorders, 12(1), 32-51. 고유경, 김수진 (2010). 기능적 조음음운장애아동과 일반아동의 음운인식과 읽기능력의 비교 및 상관. Communication Sciences \& Disorders, 15(2), 157-167.

김미배, 배소영 (2007). 유치원, 초등 $2 \cdot 4$ 학년의 낱말재인 및 음운 인식 능력. 언어치료연구, 16(2), 89-107.

김선정, 김영태 (2006). 음운생략과제를 통한 5 6세 아동의 음운 인식 발달 및 음운처리 능력과의 상관도 연구. Communication Sciences \& Disorders, 11(3), 16-28.

김수진, 오경아, 서은영, 고유경 (2018). 연령과 성에 따른 음운인 식 탈락과제 수행력: 학령전기 아동을 위한 음운인식 선별검 사 개발. 말소리와 음성과학, 10(2), 61-68.
김애화, 유현실, 김의정 (2010). 음운인식, 빠른 자동 이름대기, 자 모지식, 단기기억, 작동기억과 한글 단어인지 능력 간의 관련 성에 관한 연구: 읽기장애 조기선별을 위한 기초연구. 특수교 육학연구, 45(1), 247-267.

김영태, 성태제, 이윤경 (2011). 취학전 아동의 수용언어 및 표현 언어 발달척도(PRES). 서울: 서울장애인종합복지관.

김영태, 홍경훈, 김경희, 장혜성, 이주연 (2009). 수용표현어휘력 검사 (REVT). 서울: 서울장애인종합복지관.

김정림, 강은희, 이지윤(2018). 음운인식 중재 프로그램이 지적장 애 아동의 음운인식 및 단어재인 능력에 미치는 효과. 언어치 료연구, 27(3), 1-12.

김지윤, 강민경, 김영태(2019). 음운인식 음운작업기억 훈련이 초 등학교 저학년 읽기부진 아동의 읽기능력에 미치는 효과. 특 수교육, 18(2), 5-28.

\footnotetext{
* 본 연구는 한국연구재단 BK21 플러스의 지원을 받았음
} 
문수백, 변창진 (2003). 카우프만 아동지능검사 $(K-A B C)$. 서울: 학 지사 심리검사연구소.

박향아 (2000). 아동의 음운인식 발달. 아동학회지, $21(1), 35-44$.

신영주, 서유경, 안성우 (2006). 아동의 언어능력 수준에 따른 음 운인식 특성 비교 연구: 언어영재, 일반, 언어발달지체 아동을 중심으로. 언어치료연구, 15(4), 91-113.

신혜정, 박희정, 장현진 (2009). 4세 6세 아동의 음절 및 음소인 식 능력 발달 연구. 언어치료연구, 18(3), 99-114.

안성우, 허민정, 김유, 김미경 (2011). 4세 7세 유아의 음운인식 능력 발달 특성에 대한 대(규모) 집단 연구. 언어치료연구, 20(3), 121-141.

양유나, 배소영 (2018). 초등 1 학년 발달성 난독 아동의 낱말 해독, 음운인식, 빠른 이름대기, 자소 지식. 말소리와 음성과학, 10(2), 51-60.

임동선, 김신영, 양윤희 (2015). 정보처리 특성에 따른 작업기억 과제의 탐색적 요인분석: 일반아동 및 수용어휘지체 아동의 수용어휘력 및 빠른우연학습 예측요인. Communication Sciences \& Disorders, 20(2), 304-318.

임동선, 김신영, 유지원, 이윤정, 이상언, 정하은 (2017). 채점단위 및 수행조건에 따른 작업기억 과제의 언어장애 진단정확도 비 교 연구. Communication Sciences \& Disorders, 22(3), 485-499.

임동선, 양윤희, 조연주, 이지연, 성지민 (2015). 학령전기 단순언 어장애 및 일반아동의 문법성 메타언어인식과 집행기능 수행 능력 비교분석. 언어치료연구, 24(4), 345-359.

정일권, 최선영, 하지완 (2015). 조음음운장애아동과 일반아동의 음운표상 내적 인식능력 비교. Communication Sciences \& Disorders, 20(1), 48-59.

홍성인, 전세일, 배소영, 이익환 (2002). 한국 아동의 음운인식 발 달. Communication Sciences \& Disorders, 7(1), 49-64. 